\title{
Evaluating the Influence of Additives on Swelling Characteristics of Expansive Soils
}

\author{
N. Gangadhara Reddy • Janardhan Tahasildar • \\ B. Hanumantha Rao
}

Received: 8 December 2014 / Accepted: 11 January 2015/Published online: 20 January 2015

(C) Springer International Publishing AG 2015

\begin{abstract}
Stabilization is one of the most preferred techniques of dealing with expansive soils. Several types of additives have been evolved and are successfully being used for this purpose. This paper evaluates the performance of a variety of additives categorized into (a) cementitious: lime and fly ash (b) non-cementitious: stone dust, and (c) chemical additives: $\mathrm{CaCl}_{2}$ and $\mathrm{Na}_{2} \mathrm{SiO}_{3}$, when employed to stabilize three types of expansive soils used in the study. Attempts were also made to investigate the influence of valence of cations (viz., monovalent, divalent and trivalent) and mean particle diameter $\left(d_{50}\right)$ of additive(s) on percentage reduction of swelling characteristics. Results reveal that each additive exhibits distinct response on the swelling behavior of expansive soils. It has been observed that chemical additives exhibit superior performance over cementitious and non-cementitious additives in reducing the swelling characteristics. Further, it has also been found that valence has profound influence on the swelling characteristics of expansive soils. As such, the degree of reduction of swelling was found significantly high when employed chemical additive consists of trivalent cations than its counterpart additive consists of mono- or divalent cations. Further, efforts were also devoted to correlate mean particle diameter of additives with swelling characteristics, and it was clearly evident from trends that an appreciable decrease in swelling characteristics occurs with decrease in mean particle diameter.
\end{abstract}

Keywords Expansive soils - Swelling characteristics · Additive $\cdot$ Valence of cations $\cdot$ Mean particle diameter

N. G. Reddy · J. Tahasildar · B. H. Rao ( ()

School of Infrastructure, IIT Bhubaneswar, Samantapuri, Bhubaneswar 751013, India

e-mail: bhrao@iitbbs.ac.in

\author{
List of symbols \\ $d_{50} \quad$ Mean particle diameter of additive $(\mathrm{mm})$ \\ $S \quad$ Swell potential (\%) \\ $S_{\mathrm{p}} \quad$ Swell pressure $(\mathrm{kPa})$ \\ $G_{\mathrm{s}} \quad$ Specific gravity of soil \\ $\gamma_{\mathrm{d}}, \gamma_{\mathrm{dmax}}$ Maximum dry density $\left(\mathrm{kN} / \mathrm{m}^{3}\right)$ \\ $\Delta H \quad$ Change in height of sample during swelling test \\ (mm) \\ $H \quad$ Height of the sample (mm) \\ $w_{\mathrm{L}} \quad$ Liquid limit (\%) \\ $w_{\mathrm{P}} \quad$ Plastic limit (\%) \\ $w_{\mathrm{PI}} \quad$ Plasticity index $(\%)$ \\ OMC Optimum moisture content (\%)
}

\section{Introduction}

Damage/distress caused to the infrastructure when constructed on/in expansive soils is significant and is well recognized by the research community $[1,2]$. Stabilization of these problematic soils by employing a suitable additive(s) is one of the preferred techniques of dealing with such soils. Numerous additives have been evolved over the past few decades, and their usefulness and efficiency have been well demonstrated by the previous researchers [3-11]. As such, a variety of additives, which are being employed to stabilize the expansive soils for some time, can broadly be classified into three main categories: cementitious, noncementitious and chemical additives, as listed in Table 1.

Among several additives, lime is the most extensively being used additive, and expansive soil stabilization with this additive is the common traditional practice being followed [12-16]. Although, lime stabilization is well suited 
Table 1 Categorization of various additives used for stabilization of expansive soils

\begin{tabular}{ll}
\hline Additive & Category \\
\hline $\begin{array}{l}\text { Stone dust, quarry dust, aggregate waste, rock waste powder, } \\
\text { crusher dust, granite saw dust, sand }\end{array}$ & Non-cementitious additives \\
$\begin{array}{l}\text { Lime, fly ash, ground-granulated blast furnace slag (GGBS), cement kiln dust, } \\
\text { lime kiln dust, silica fume }\end{array}$ & Supplementary cementitious additives \\
$\mathrm{CaCl}_{2}, \mathrm{KCl}, \mathrm{Na}_{2} \mathrm{SiO}_{3}, \mathrm{FeCl}_{3}, \mathrm{Mg}(\mathrm{OH})_{2}, \mathrm{Na}(\mathrm{OH}), \mathrm{NaCl}, \mathrm{MgCl}_{2}, \mathrm{AlCl}_{3}$ & Chemical additives \\
\hline
\end{tabular}

for almost any type of expansive soil and is economically available additive, constructability issues often make its usage not feasible for all real life conditions. In addition, effective lime-soil reaction demands elevated temperature that is greater than $40^{\circ} \mathrm{F}$. Below this temperature, lime usually remains in a dormant state and does not initiate the reaction.

In order to overcome these limitations, researchers have been resorting to employ chemical additive such as $\mathrm{KCl}$, $\mathrm{NaCl}, \mathrm{MgCl}_{2}, \mathrm{CaCl}_{2}, \mathrm{AlCl}_{3}$, etc., as stabilizing agents [10, 17-22]. The readily soluble capacity in water, which results in supply of adequate number of cations for ionexchange reaction, is the principal merit of using these chemical additives as compared with the conventional additives [17, 23, 24]. Most importantly, in several field applications, where the soil at the site predominately contains clay size particles, a free passage of liquids and longer wetting periods is essential. Under these circumstances, use of chemical additives are found to be greatly effective than other non-chemical additives [21, 25-28].

Though, chemical additives were proved to be efficient in reducing the swelling characteristics of expansive soils, their utility in an economical way is not justifiable [4, 29, 30]. In this scenario, use of alternate materials such as fly ash, stone dust, quarry dust, cement kiln dust, lime kiln dust, marble dust, granite saw dust, ground granulated blast furnace slag, and so on, which are highly costeffective and available in abundance, seems to be promising [3, 4, 8, 31]. Moreover, disposal of these waste materials is not only cost-intensive, but also requires usable land that can be utilized for cultivation or for other purposes. Thus, utilization of these wastes and by-products in stabilization of expansive soils could possibly be one of the valuable applications that can be regarded as an economical and effective way of dealing with such materials. As such, efforts were also devoted in this direction, which highlight that these materials can be used either in isolation or in blending with other alternate additives [4].

However, the performance and efficiency of any additive are strongly influenced by chemical and mineralogical composition of soil, properties of additives, and type of construction. Other factors include type and amount of clay mineral, soil-water chemistry, cations, initial moisture content, initial dry density, soil structure and fabric, soil profile, loading conditions and so on, which strongly influence the swelling characteristics of expansive soils [4, 30]. Although, soil stabilization is being practiced for many years, varying degree of success has been reported [16, 3235]. Furthermore, most of the studies remain confined to employ a single additive either in isolation or mixed with other suitable additive(s). As such, very few efforts were devoted to evaluate the performance among several types of additives that have been employed for stabilization of expansive soils.

In this study, attempts were made to evaluate the performance of a variety of additives ranging from cementitious to non-cementitious to chemical additives when employed to stabilize three types of expansive soils. Five types of additives such as fly ash, lime (categorized as cementitious additives), stone dust (categorized as noncementitious additive), and $\mathrm{CaCl}_{2}$ and $\mathrm{Na}_{2} \mathrm{SiO}_{3}$ (categorized as chemical additives) were used. Results reveal that all the five additives are effective in reducing the swelling characteristics of expansive soils and each additive exhibits entirely different response. In general, it has been observed that the swelling characteristics of expansive soils decrease with an increase in additive content. Further, the performance of chemical additives is observed to be superior over other two categories of additives. Efforts were also made to study the influence of (a) valence of cations (i.e. monovalent, divalent and trivalent) and (b) mean particle diameter $\left(d_{50}\right)$ of additive(s) on swelling characteristics of expansive soils. Trends plotted between valence and swelling characteristics clearly indicate the influence of valence such that the chemical additives consisting of higher valence (i.e. trivalent) exhibit greater efficiency than those additives consisting of lower valence (i.e. mono-and divalent). In addition, attempts were also made to correlate the mean particle diameter of additive(s) with swelling characteristics of expansive soils. A linear variation when plotted for mean particle diameter of additive against swelling characteristics was noticed with a considerable reduction in swelling characteristics with decrease in mean particle diameter of additive. The results clearly highlight that variety of additives can be employed for stabilization of three expansive soils used in the study. But, factors such as cost, benefit, practicality, and availability shall be taken 
into account when selecting a particular type of additive for stabilization of expansive soils.

\section{Experimental Investigations}

\section{Soil Sample Collection}

Expansive soils were collected from Amalapuram (denoted as $\mathrm{AM}$ ) and Bhimavaram (denoted as BV) regions of Andhra Pradesh state, India, and Warangal (denoted as W) region of Telengana state, India. All samples were collected in their disturbed state and from a sufficient depth below the ground surface (i.e. $0.8-1.0 \mathrm{~m}$ ) in order to avoid grabbing of roots and vegetation during sample collection. These samples were later dried and processed by pulverizing with the help of a wooden mallet. The processed samples were then subjected to various experimental investigations to establish their physical, chemical, geotechnical, and swelling characteristics.

\section{Physical Characteristics}

The specific gravity, $G_{\mathrm{s}}$, of a sample was determined by pycnometer bottle method in accordance with the ASTM standard [36]. For the sake of accuracy, average value obtained from tests conducted in triplicate was considered representative, as listed in Table 2. Grain size distribution characteristics and consistency limits of soils used in the study were established in accordance with the ASTM standards [37, 38]. The results obtained are presented in Table 2. These soils have been classified as per unified soil classification system (in accordance with the ASTM

Table 2 Physical and geotechnical characteristics of three expansive soils used in the study

\begin{tabular}{|c|c|c|c|c|c|}
\hline Parameter & AM & BV & W & Fly ash & Stone dust \\
\hline$G_{\mathrm{s}}$ & 2.56 & 2.60 & 2.58 & 2.55 & 2.68 \\
\hline \multicolumn{6}{|c|}{ Grain size distribution $(\%)$} \\
\hline Gravel & 2 & 2 & 3 & 0 & 0 \\
\hline Sand & 25 & 26 & 26 & 28 & 96 \\
\hline Silt and clay & 73 & 72 & 71 & 72 & 4 \\
\hline \multicolumn{6}{|c|}{ Atterberg's limits } \\
\hline$w_{\mathrm{L}}(\%)$ & 98 & 76 & 64 & 30 & NP \\
\hline$w_{\mathrm{P}}(\%)$ & 36 & 30 & 26 & - & \\
\hline$w_{\mathrm{PI}}$ & 62 & 46 & 38 & - & \\
\hline \multicolumn{6}{|c|}{ Compaction characteristics } \\
\hline$\gamma_{\mathrm{d}}\left(\mathrm{kN} / \mathrm{m}^{3}\right)$ & 16.2 & 16 & 16.4 & 14 & - \\
\hline $\mathrm{OMC}(\%)$ & 26 & 25 & 23 & 18 & - \\
\hline $\mathrm{USCS}^{\mathrm{a}}$ & $\mathrm{CH}$ & $\mathrm{CH}$ & $\mathrm{CH}$ & SM & SW \\
\hline
\end{tabular}

${ }^{a}$ [39] standard [39], and the same has been reported in Table 2. It has been found that all the three soils fall under the category of highly compressible clays (i.e. $\mathrm{CH}$ ).

\section{Additives Used and Mix Proportions}

In the present study, five different types of additives such as fly ash, lime, stone dust, $\mathrm{CaCl}_{2}$, and $\mathrm{Na}_{2} \mathrm{SiO}_{3}$, respectively, were used to stabilize three expansive soils. Based on their nature and characteristics, these additives have been categorized into (a) cementitious additives: fly ash and lime, (b) non-cementitious additives: stone dust, and (c) chemical additives: $\mathrm{CaCl}_{2}$ and $\mathrm{Na}_{2} \mathrm{SiO}_{3}$. The fly ash used was collected from Vijayawada thermal power station, Vijayawada, Andhra Pradesh, India. Stone dust and lime were collected from manufacturing units located in the region of Guntur, Andhra Pradesh, India. The chemical compositions of fly ash and lime are listed in Table 3. The solutions of $\mathrm{CaCl}_{2}$ and $\mathrm{Na}_{2} \mathrm{SiO}_{3}$ have been prepared from the analytical grade salts. For stabilization of expansive soils, each additive in isolation, but in varying proportions, was mixed with expansive soil during stabilization. Table 4 presents list of various additives and the corresponding proportions in percentages adopted for stabilization of expansive soils.

\section{Compaction Characteristics}

The compaction characteristics of (a) three virgin expansive soils and (b) expansive soil blended with an additive in various mix proportions were established by adopting standard Proctor compaction technique in accordance with the ASTM standard [40]. Results obtained are presented in Table 5. However, the compaction characteristics of soils

Table 3 Chemical composition of fly ash and lime used in the study (\% by weight)

\begin{tabular}{cl}
\hline Oxide & Value \\
\hline Fly ash & \\
$\mathrm{SiO}_{2}$ & $61-64.29$ \\
$\mathrm{Al}_{2} \mathrm{O}$ & $21.6-27.04$ \\
$\mathrm{Fe}_{2} \mathrm{O}$ & $3.09-3.86$ \\
$\mathrm{TiO}_{2}$ & $1.25-1.69$ \\
$\mathrm{MgO}$ & $0-0.05$ \\
$\mathrm{CaO}$ & $1.02-3.39$ \\
$\mathrm{P}_{2} \mathrm{O}_{5}$ & $0.02-0.14$ \\
$\mathrm{SO}_{3}$ & $0-0.07$ \\
$\mathrm{~K}_{2} \mathrm{O}$ & $0.08-1.83$ \\
$\mathrm{Na}_{2} \mathrm{O}$ & $0.26-0.48$ \\
$\mathrm{Lime}$ & \\
$\mathrm{CaO}$ & 58.64 \\
$\mathrm{SiO}_{2}$ & 7.3 \\
\hline
\end{tabular}


Table 4 Percentage proportion of various additives adopted for stabilization of three expansive soils

\begin{tabular}{ll}
\hline Name of additive & $\%$ Added \\
\hline Lime & $0,2,4,6,8,10$, and 12 \\
Fly ash & $0,10,15,20,25,30,40$, and 50 \\
Stone dust & $0,10,15,20,25,30,40$, and 50 \\
$\mathrm{CaCl}_{2}$ & $0,0.5,1.0,1.5$, and 2.0 \\
$\mathrm{Na}_{2} \mathrm{SiO}_{3}$ & $0,0.5,1.0,1.5$, and 2.0 \\
\hline
\end{tabular}

blended with chemical additives such as $\mathrm{CaCl}_{2}$ and $\mathrm{Na}_{2}$ $\mathrm{SiO}_{3}$, were not established.

\section{Swelling Characteristics}

Swelling characteristics such as swell potential, $S$, and swell pressure, $S_{\mathrm{p}}$, of each soil were determined with the help of a conventional oedometer apparatus, which consists of a metallic cylindrical ring of internal diameter $60 \mathrm{~mm}$ and height $20 \mathrm{~mm}$. It has been well documented that expansive soils undergo maximum volume change when compacted at a maximum dry density $\left(\gamma_{\text {dmax }}\right)$ with optimum moisture content (OMC) [41]. Thus, all swell tests were conducted considering the compaction state of $\gamma_{\mathrm{dmax}}$ and OMC (refer to Table 5).

Soil samples on which swelling tests to be carried out were oven dried and pulverized such that all particles are passing through $425 \mu \mathrm{m}$ sieve. Initially, the prepared soil sample was mixed with respective additive (viz., fly ash or lime or stone dust or $\mathrm{CaCl}_{2}$ or $\mathrm{Na}_{2} \mathrm{SiO}_{3}$ ) and blended thoroughly in their dry state. Subsequently, desired amount of distilled water was added to this mixture and the process of blending was continued again until a uniform consistency in the soil sample was ensured. The prepared sample was then compacted in the consolidation ring up to the desired height, $H$. It can be noted here that $H$ shall not be exceeding that of the height of the ring. Such arrangement avoids swelling of soil sample beyond the height of the ring and also facilitates compression of the soil sample to its original height when applying swell pressure. The ring with soil sample was then placed in the consolidation set-up to proceed for the swelling experimentation. Prior to commencement of the test, porous stones, saturated by boiling in distilled water for about $15 \mathrm{~min}$, were placed on both side of the sample. In addition, pair of filter papers (make, Whatman No. 1) was also inserted between soil sample and porous stone in order to avoid intrusion of soil particles into the porous stone.

After ensuring the entire assembly of the ring was properly placed in the set-up, the loading block was positioned centrally on top of the porous stone such that the vertical compressive load when applied was transmitted to the soil specimen through the loading cap uniformly. As the lever loading system was used the apparatus was
Table 5 Compaction characteristics of various mix proportions

\begin{tabular}{|c|c|c|c|c|c|c|c|}
\hline \multirow[t]{2}{*}{ Additive } & \multirow[t]{2}{*}{$\%$ Added } & \multicolumn{2}{|l|}{ AM } & \multicolumn{2}{|l|}{ BV } & \multicolumn{2}{|l|}{ W } \\
\hline & & OMC (\%) & $\gamma_{\mathrm{d}}\left(\mathrm{kN} / \mathrm{m}^{3}\right)$ & OMC (\%) & $\gamma_{\mathrm{d}}\left(\mathrm{kN} / \mathrm{m}^{3}\right)$ & OMC (\%) & $\gamma_{\mathrm{d}}\left(\mathrm{kN} / \mathrm{m}^{3}\right)$ \\
\hline \multirow[t]{7}{*}{ Fly ash } & 10 & 23.65 & 16.5 & 22.6 & 16.3 & 21.15 & 16.7 \\
\hline & 15 & 22.75 & 16.7 & 22.6 & 16.7 & 20.25 & 16.9 \\
\hline & 20 & 22.3 & 17.1 & 22.15 & 16.95 & 19.8 & 17.44 \\
\hline & 25 & 21.35 & 17.6 & 22.1 & 17.51 & 19.2 & 18 \\
\hline & 30 & 20.95 & 17.7 & 20.66 & 17.62 & 18.4 & 18.1 \\
\hline & 40 & 20.1 & 17.8 & 19.76 & 17.72 & 17.2 & 18.2 \\
\hline & 50 & 19.7 & 17.9 & 18.9 & 17.79 & 16.6 & 18.3 \\
\hline \multirow[t]{6}{*}{ Lime } & 2 & 26.9 & 16.73 & 25.8 & 16.7 & 25.6 & 16.8 \\
\hline & 4 & 27.3 & 17.6 & 26.1 & 18 & 28.1 & 18.3 \\
\hline & 6 & 27.65 & 17.7 & 26.5 & 18.1 & 27.4 & 18.54 \\
\hline & 8 & 27.85 & 17.8 & 26.85 & 18.2 & 28.85 & 18.57 \\
\hline & 10 & 27.9 & 17.9 & 26.98 & 18.3 & 29.19 & 18.6 \\
\hline & 12 & 27.86 & 17.8 & 27.12 & 18.2 & 29.05 & 18.65 \\
\hline \multirow[t]{7}{*}{ Stone dust } & 10 & 19.9 & 16.7 & 20.42 & 16.5 & 17.1 & 17 \\
\hline & 15 & 19.15 & 17 & 19.61 & 16.9 & 16.39 & 17.5 \\
\hline & 20 & 18.4 & 17.5 & 18.93 & 17.4 & 15.65 & 17.9 \\
\hline & 25 & 18 & 17.9 & 17.83 & 17.8 & 14.35 & 18.4 \\
\hline & 30 & 17.65 & 18.5 & 17.53 & 18.3 & 14.08 & 18.9 \\
\hline & 40 & 16.4 & 18.6 & 14.9 & 18.4 & 12.41 & 18.94 \\
\hline & 50 & 13.84 & 18.61 & 13 & 18.42 & 11 & 18.99 \\
\hline
\end{tabular}


properly counterbalanced. Dial gauge, which measures the progressive vertical heave of the specimen, was fastened to the stand with its end-release touching perfectly on the loading block. An initial seating pressure of $5 \mathrm{kPa}$ was placed on the loading hanger and the initial reading of the dial gauge was noted. The system was then connected to water reservoir to allow water ingress into the sample, which accelerates the swelling process. The free swell readings shown by the dial gauge were recorded at regular intervals of time. The swelling test was continued until there was no change in three consecutive dial gauge readings, which can be designated as a state of equilibrium, was recorded. For the samples used in the study, the state of equilibrium was noticed after about 3 days of experimentation. After successful completion of the test, the difference in height, $\Delta H$, was computed by subtracting the initial height from the final height of the sample. Thus, swell potential of a sample can be computed using the following equation:

$S(\%)=\frac{\Delta H}{H} \times 100$,

where, $S$ is the swell potential, $H$ is the initial height of the sample, and $\Delta H$ is the difference in height of sample.

From the stage of equilibrium, which would represent the maximum swell potential of a soil, vertical compressive load was applied to determine the swell pressure exhibited by a soil. This was achieved by applying a vertical compressive load in increments. Each imposed load was maintained until no change in dial gauge reading was recorded. Loading on the sample was continued till heave becomes zero or the sample has been compressed to its initial height. The load at which the sample is compressed to its initial height can be designated as the swelling pressure of a soil.

Following the above procedure, swelling characteristics have been established on all soil samples prepared with the composition and mix proportions, as listed in Tables 4 and 5 , respectively.

\section{Results and Discussion}

The degree of expansive potential of three soils (AM, BV and $\mathrm{W}$ ) used in the present study was identified as per the classification system proposed by Snethen [42], Dakshanamurthy and Ramana [43], Sowers and Sowers [44], and Grabowska-Olszeawska [45]. These classification systems primarily employ consistency limits as input parameters. All the methods predominantly classify that the soils are to be 'very high expansive potential' in nature, as depicted in Table 6. Since, the soils were identified as expansive in nature they were stabilized with the help of various additives such as stone dust, fly ash, lime, $\mathrm{CaCl}_{2}$, and $\mathrm{Na}_{2} \mathrm{SiO}_{3}$.

As depicted in Figs. 1 and 2, respectively, variations of $S$ and $S_{\mathrm{p}}$ with percentage additive content was obtained corresponding to three soils $\mathrm{AM}, \mathrm{BV}$ and $\mathrm{W}$ used in the study. In general, it can be seen from the plots that both $S$ and $S_{\mathrm{p}}$ decrease with increase in percentage additive content indicating their usefulness in stabilizing three types of expansive soils. As depicted in the figures, it is clearly evident that the type and nature of additive (i.e. cementitious, non-cementitious or chemical) have a significant influence on stabilization of an expansive soil and results also reveal that percentage of additive required for stabilization of soils AM, BV and $\mathrm{W}$ is different for different additives. Further, it can also be noticed that each additive exhibits distinct response showing its effect on the swelling behavior of expansive soils. As depicted in Figs. 1 and 2, respectively, trends show that approximately 30, 10, 40, 1.0 , and $1.5 \%$, respectively, correspond to fly ash, lime, stone dust, $\mathrm{CaCl}_{2}$, and $\mathrm{Na}_{2} \mathrm{SiO}_{3}$, respectively, both $S$ and $S_{\mathrm{p}}$ attained constant values. The findings are in good agreement with those results reported by other researchers [31, $46,47]$ for similar types of additives. Incidentally, for all the three soils, as there is no significant change in their physical and compaction characteristics, the percentage of additive content found to be almost similar. Figure 3 shows the maximum percentage of additives required for stabilization of soils AM, BV and $\mathrm{W}$, respectively.

From the Figs. 1 and 2, respectively, it is obvious that efficiency among cementitious additives like fly ash and lime, the performance of fly ash is significantly lower than that of lime in reducing $S$ and $S_{\mathrm{p}}$. When lime is added to the soil, it causes (a) cation exchange, in which the positively charged ions react with negatively charged clay particles, and (b) flocculation-agglomeration. The combination of these two phenomena in tandem allows the small clay particles to floc together resulting agglomerate into larger clay flocs $[4,26,48-50]$. In addition, the addition of lime to soil provides an adequate number of cations, which can readily take part in exchange of cations present on clay

Table 6 Classification of degree of swell potential of soils used in the study

\begin{tabular}{lllll}
\hline Soil & $\begin{array}{l}\text { Snethen } \\
{[42]}\end{array}$ & $\begin{array}{l}\text { Dakshanamurthy } \\
\text { and Ramana [43] }\end{array}$ & $\begin{array}{l}\text { Sowers and } \\
\text { Sowers [44] }\end{array}$ & $\begin{array}{l}\text { Grabowska- } \\
\text { Olszeawska } \\
{[45]}\end{array}$ \\
\hline AM & VH & VH & H & VH \\
BV & VH & VH & H & H \\
W & VH & VH & H & H \\
\hline
\end{tabular}

$H$ high, $V H$ very high 

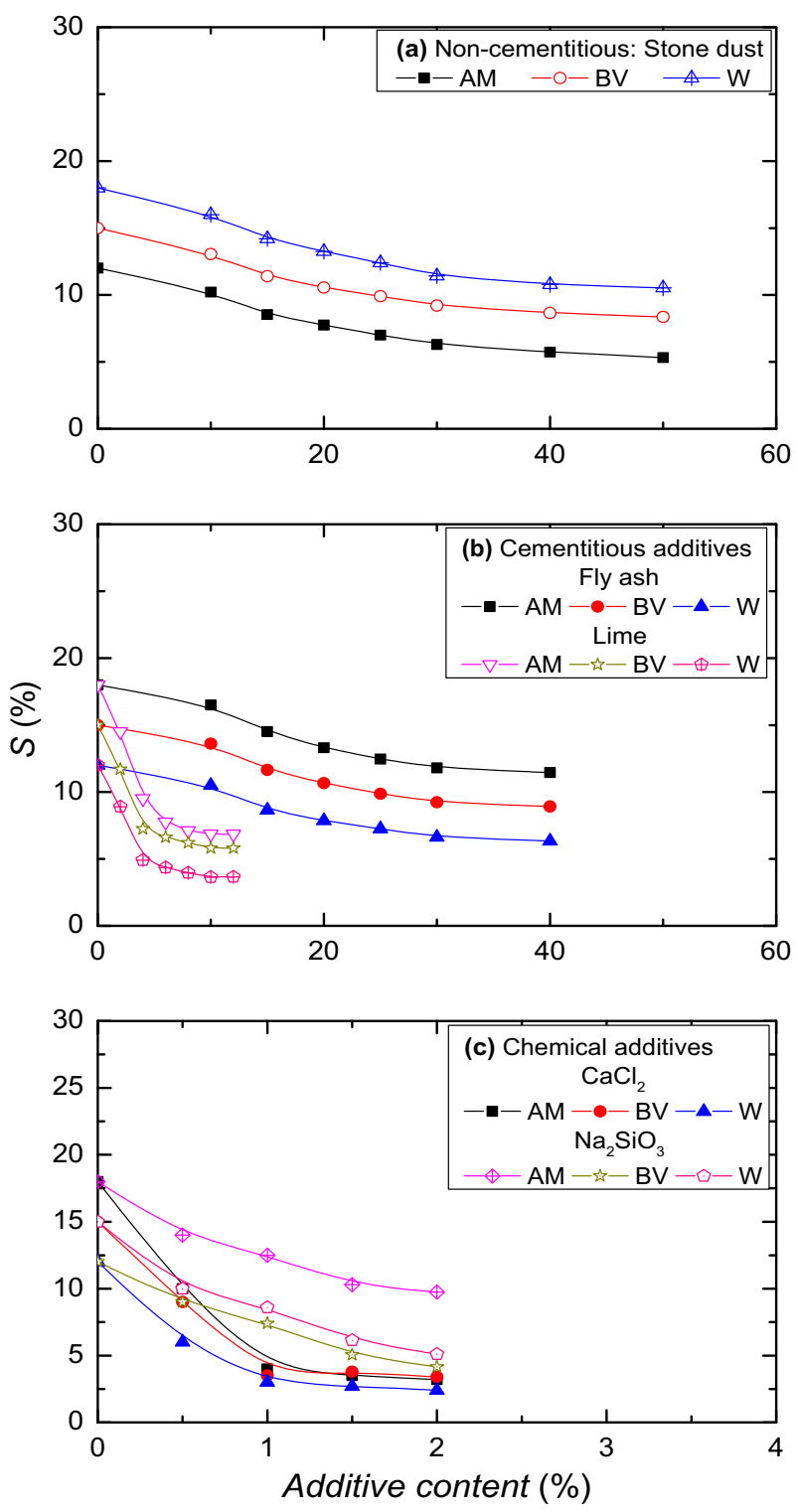

Fig. 1 Reduction in swell potential with varying proportions of additive content a non-cementitious additive $\mathbf{b}$ cementitious additives and $\mathbf{c}$ chemical additives

particles surface. Thus, the net result is a substantial decrease in swelling characteristics of expansive soils. Moreover, the reaction between lime and water, which usually occurs after sufficiently long time, forms a cementitious matrix resulting resistance to volumetric expansion of soil to an appreciable extent [51]. Overall, when lime is added to soil, reduction in $S$ and $S_{\mathrm{p}}$ occurs primarily because of alteration in clay structure.

However, the reaction between fly ash and soil is a complex phenomenon as it contains an array of cations (like $\mathrm{Na}^{+}, \mathrm{Ca}^{2+}, \mathrm{K}^{+}, \mathrm{Fe}^{3+}$, and so on) and a considerable amount of silt size particles. Thus, when fly ash is added to the soil, reduction in swell behavior is attributed to the
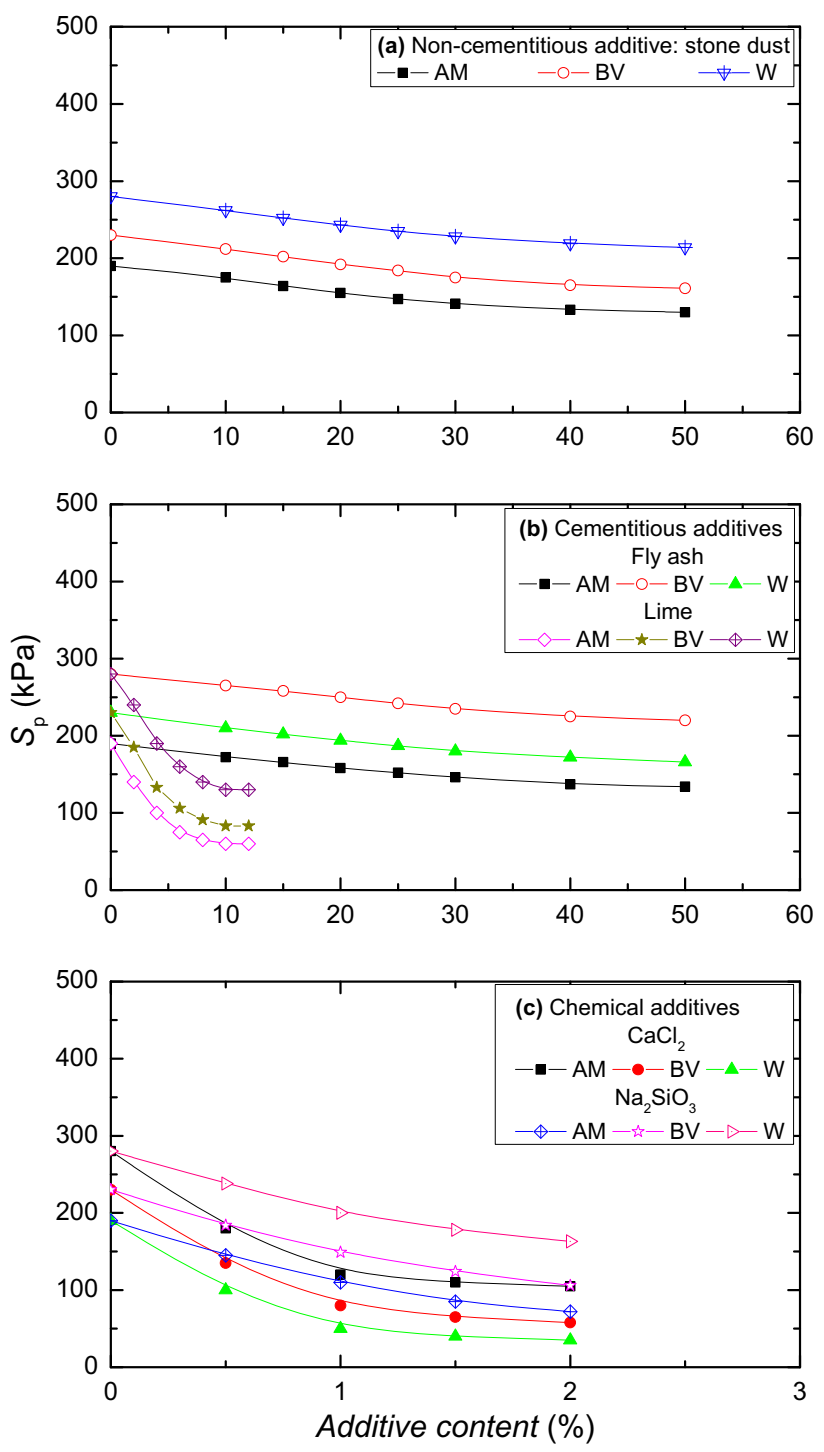

Fig. 2 Reduction in swell pressure with variation of additive content $\mathbf{a}$ non-cementitious additive $\mathbf{b}$ cementitious additives and $\mathbf{c}$ chemical additives

presence of silt size particle, to some extent, and due to the immediate effect of chemical reactions because of an array of cations present in fly ash, to the rest, [3]. As such, the amount of free lime available in fly ash is quite less and hence, ion-exchange occurrence between fly ash and soil is negligible. Thus, less reduction in $S$ and $S_{\mathrm{p}}$ of expansive soils can be expected as compared to lime [52]. Similarly, the performance of non-cementitious additive like stone dust in reducing $S$ and $S_{\mathrm{p}}$ also observed to be low when compared to its counterpart additives. This may be because stone dust merely acts as a fill material within the pore space of the soil mass as it does not show affinity to water, and it also creates a contrast in density of particles between additive and parent soil [53]. 
Attempts were made to highlight the relative performance among a variety of additives, as depicted in Fig. 4, which shows the percentage reduction of both $S$ and $S_{\mathrm{p}}$ with additive type. It is apparent from the chart that the performance of chemical additives in reducing the swelling behavior of expansive soils is superior over its counterparts like cementitious and/or non-cementitious additives. As such, Figs. 1 and 2, respectively, also confirm similar such

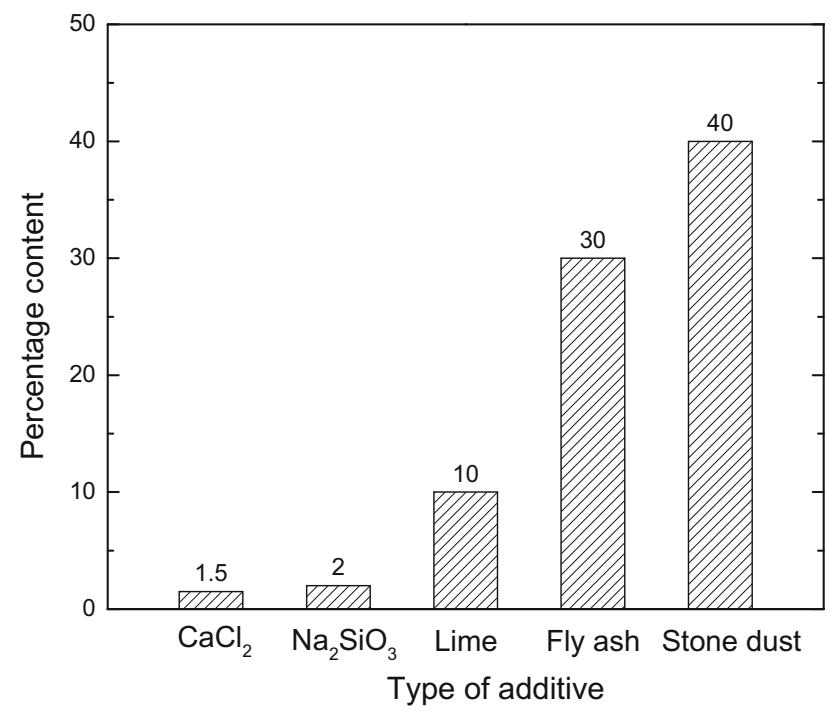

Fig. 3 Maximum percentage of additive for stabilization of expansive soils used in the study findings. Interestingly, all the additives show better performance in reducing $S_{\mathrm{p}}$ than $S$ of a soil. Further, to comprehend the influence of various categories of additives on the stabilization process in a much better way, the results of both $S$ and $S_{p}$ in their reduced percentage intensity form were superimposed into a single graph, as depicted in Fig. 5. From the graph, it is evident that the performance efficiency increases in the order of noncementitious to cementitious to chemical additives.

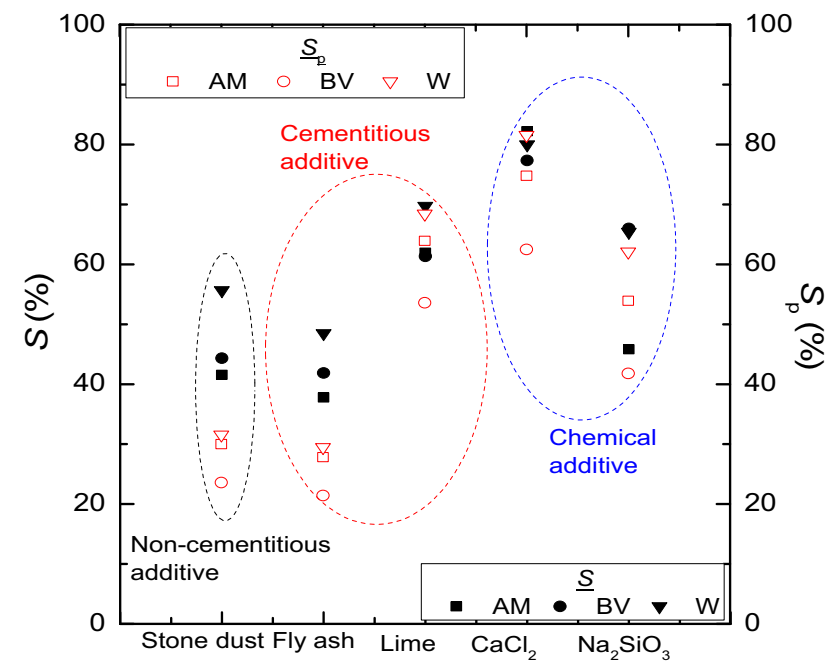

Fig. 5 Influence of category of additives on the swelling characteristics of expansive soils

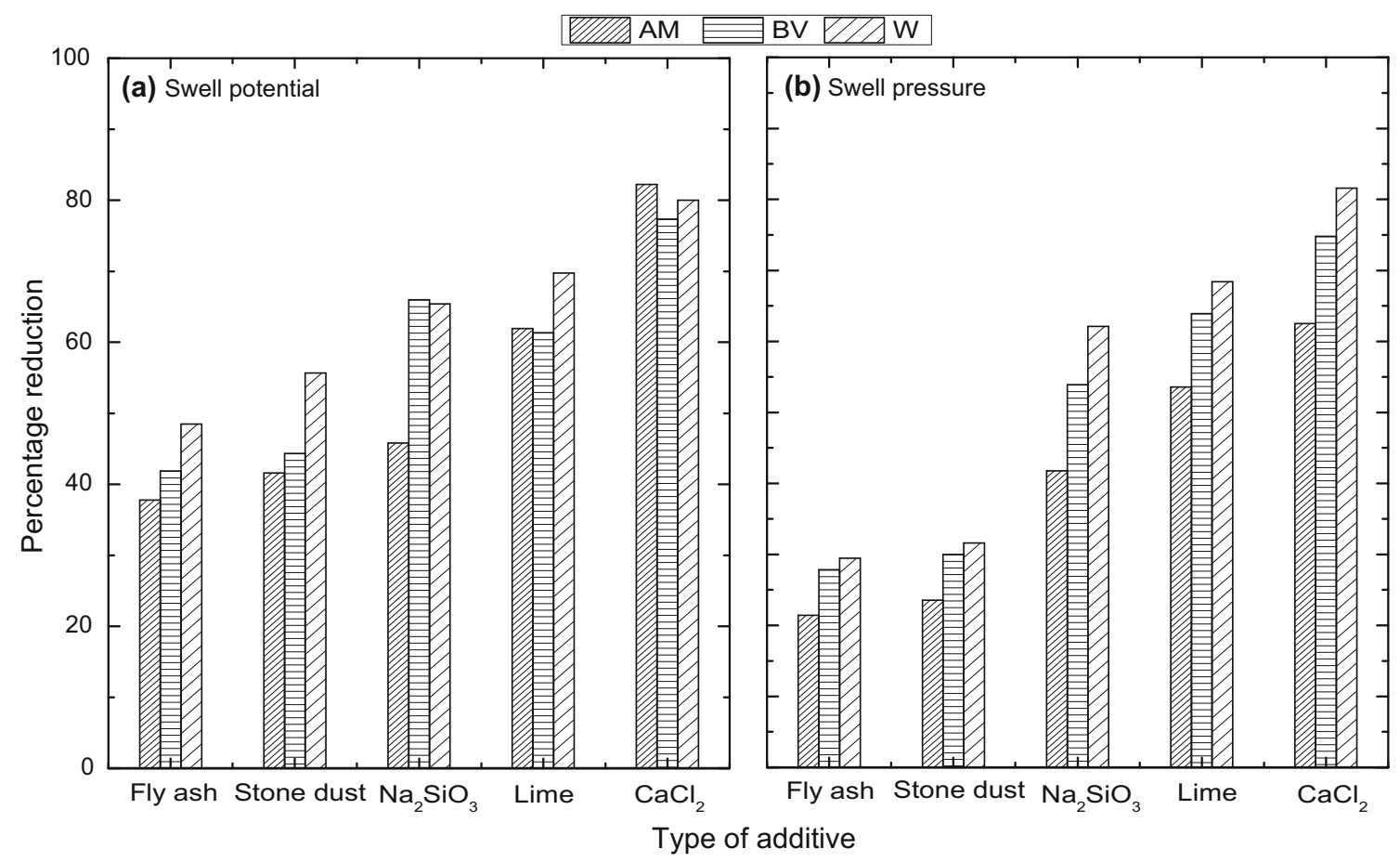

Fig. 4 Percentage reduction of $S$ and $S_{\mathrm{p}}$ with additive content 
Fig. 6 Influence of valence on the swelling characteristics of expansive soils

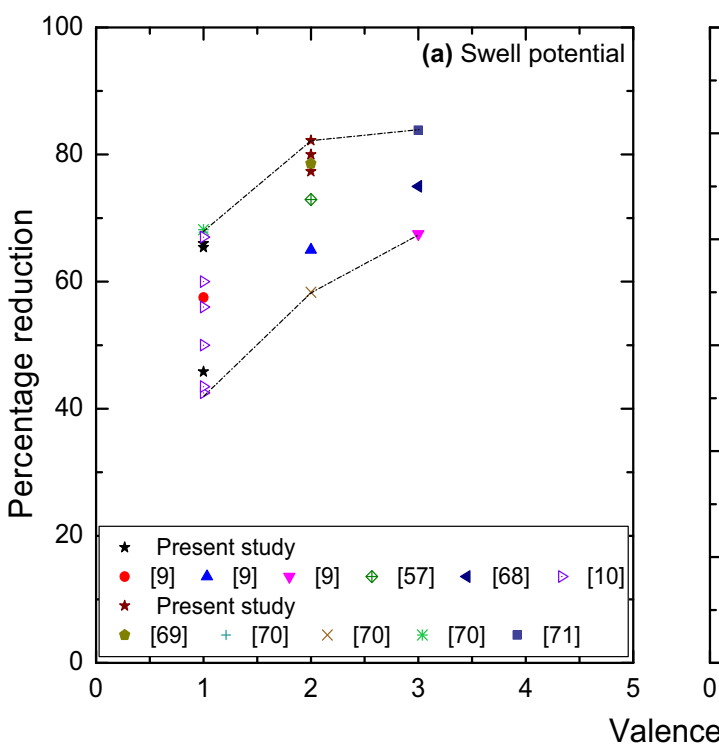

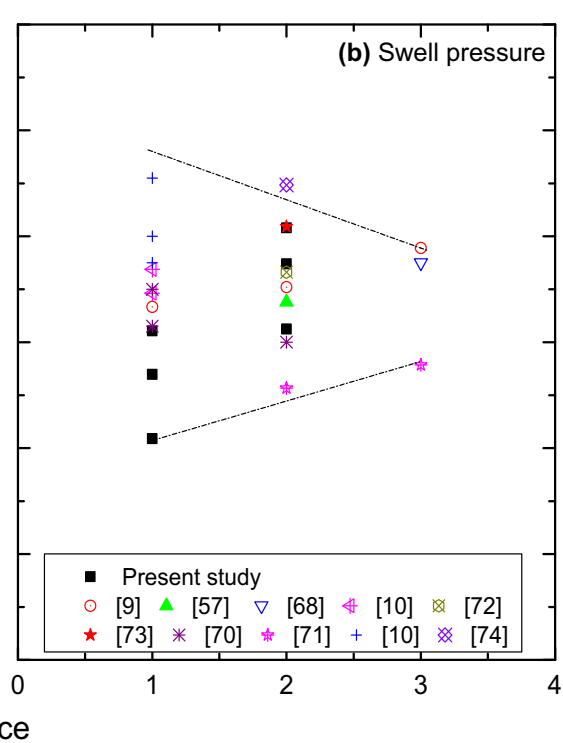

As such, Figs. 1, 2, 3 also show that the quantity of additive content in case of chemical category is significantly lesser as compared with those of cementitious or non-cementitious categories. This may be attributed to the fact that the salts in chemical additives are readily soluble (solubility of $\mathrm{CaCl}_{2}=745 \mathrm{~g} / \mathrm{l}$, and $\mathrm{Na}_{2} \mathrm{SiO}_{3}=610 \mathrm{~g} / \mathrm{l}$ ) in water as compared with lime (soluble capacity $=1.65 \mathrm{~g} / \mathrm{l}$ ). Petry and Armstrong [25] reported that when calcium chloride electrolyte is added to soil, it easily made into the calcium charged supernatant, which helps in ready cation exchange reactions with clay particles. While those of cementitious/non-cementitious additives like fly ash and stone dust, their solubility capacity in water is almost zero. Thus, the mechanism involved in reducing $S$ and $S_{\mathrm{p}}$ of soil when employed these additives is majorly due to mechanical bonding or cementation instead of an ionexchange phenomenon [54]. As such, when chemical additives are employed in place of cementitious/noncementitious additives, because of their instantaneous solubility supply an adequate numbers of cations for exchange with ions available on the surface of soil particles, which in turn leads to increase or decrease in thickness of the diffuse double layer [9, 27]. Thus, chemical additives exhibit better performance at an accelerated rate that too in substantial lesser quantity than their counterparts would do so. Incidentally, results of lime additive in reducing $S$ and $S_{\mathrm{p}}$ are very close to that of chemical additives. This may because, lime contains a considerable amount of $\mathrm{CaO}$, which in turn makes it highly reactive in nature, while a limited amount of $\mathrm{CaO}$ is available in fly ash and negligible in stone dust additives [55]. Further, a partial amount of $\mathrm{CaO}$ in the lime also exists as non-exchanged calcium ions, which may be adsorbed onto soil particles resulting low base-exchange reaction and hence, insignificant volume change potential. In addition, the reaction between lime and water is exothermic in nature, which releases a good amount of heat energy into the soil mass resulting in evaporation of water at a faster rate, which in turn reduces the swell properties of expansive soils, rapidly [56].

\section{Influence of Valence on Swelling Characteristics}

It can be seen from Figs. 1, 2 and 5, respectively, among $\mathrm{CaCl}_{2}$ and $\mathrm{Na}_{2} \mathrm{SiO}_{3}$ additives, the efficiency of former one in reducing $S$ and $S_{\mathrm{p}}$ is prominently better than later one. This finding was in agreement with those results reported by Murty and Praveen [57] and Srinivas and Raju [9]. This is due to the fact that the additive $\mathrm{CaCl}_{2}$ contains divalent cations (i.e. $\mathrm{Ca}^{2+}$ ) as against $\mathrm{Na}_{2} \mathrm{SiO}_{3}$, which contains monovalent (i.e. $\mathrm{Na}^{+}$) cations. A base exchange occurs with the strong calcium ions replacing the weaker sodium ions (typical cation's replaceability is: $\mathrm{Na}^{+}<\mathrm{K}^{+}<-$ $\left.\mathrm{Mg}^{2+}<\mathrm{Ca}^{2+}<\mathrm{Al}^{3+}<\mathrm{Fe}^{3+}\right)$, which in turn results decrease in thickness of the diffuse double layer develops on the surface of clay particles. This alteration in electrical charge around a clay particle reduces the spacing between clay particles resulting creation of flocculated structure, which in turn reduces the swell percent and swell pressure of a soil [58-60]. Moreover, according to Gouy-Chapman theory, thickness of diffuse double layer varies inversely with valence [61]. Thus, it can be established that the chemical additive with higher valence of cations (like $\mathrm{CaCl}_{2}$ ) performs superior to than those additives with lower valence (like $\mathrm{Na}_{2} \mathrm{SiO}_{3}$ ) in reducing the swelling 
Table 7 Legend of references used in Figs. 6 and 7

\begin{tabular}{|c|c|c|}
\hline Reference & Legend & Additive \\
\hline Present study & - & $\mathrm{CaCl}_{2}, \mathrm{Na}_{2} \mathrm{SiO}_{3}$, stone dust, lime, fly ash \\
\hline Cokca et al. (2009) & {$[8]$} & $\begin{array}{l}\text { Granulated blast furnace slag, granulated } \\
\text { blast furnace slag cement }\end{array}$ \\
\hline Srinivas and Raju (2010) & [9] & $\mathrm{CaCl}_{2}, \mathrm{KCl}, \mathrm{FeCl}_{3}$ \\
\hline Gueddouda et al. (2011) & {$[10]$} & $\mathrm{NaCl}$, lime \\
\hline Cetiner (2004) & {$[16]$} & Fly ash, lime \\
\hline Murty and Praveen (2008) & {$[57]$} & $\mathrm{CaCl}_{2}$ \\
\hline Rao et al. (2012) & {$[68]$} & $\mathrm{FeCl}_{3}$ \\
\hline Abdullah and Al-Abadi (2009) & [69] & $\mathrm{CaCl}_{2}$ \\
\hline Belabbaci et al. (2013) & {$[70]$} & $\mathrm{KCl}, \mathrm{MgCl}_{2}$ \\
\hline Radhakrishnan et al. (2014) & {$[71]$} & $\mathrm{AlCl}_{3}$, fly ash \\
\hline Heeralal et al. (2012) & {$[72]$} & $\mathrm{CaCl}_{2}$ \\
\hline Urena et al. (2013) & {$[73]$} & $\mathrm{Mg}(\mathrm{OH})_{2}$ \\
\hline Azam et al. (2000) & {$[74]$} & Calcium sulfate \\
\hline Cai et al. (2006) & {$[75]$} & Polypropylene fiber \\
\hline Kalkan (2009) & {$[76]$} & Silica fume \\
\hline Nalbantoglu and Gucbilmez (2002) & [77] & Fly ash \\
\hline Nalbantoglu (2004) & [78] & Fly ash \\
\hline Zhang and Cao (2002) & [79] & Fly ash, lime \\
\hline Negi et al. (2013) & {$[80]$} & Silica fume \\
\hline ElKholy (2008) & {$[81]$} & Sand \\
\hline Siddique and Hossain (2011) & {$[51]$} & Lime \\
\hline Al-Rawas et al. (2005) & {$[82]$} & Lime \\
\hline Phanikumar (2009) & {$[83]$} & Lime \\
\hline Mousa and Al-Sharif (1998) & [84] & Burned olive waste \\
\hline Mollamahmutoglu and Yilmaz (2001) & {$[85]$} & Fly ash \\
\hline Sabat (2012) & {$[86]$} & Ceramic dust \\
\hline Bose (2012) & [87] & Fly ash \\
\hline Kalkan and Akbulut (2004) & {$[88]$} & Silica fume \\
\hline
\end{tabular}

characteristics of expansive soils. Results also highlight that cation exchange is one of the dominants phenomena in mitigating the swelling characteristics of expansive soils.

With this in view, attempts were made to investigate the influence of valence in reducing both $S$ and $S_{\mathrm{p}}$ of expansive soils. Figure 6 depicts the variation of percentage reduction of $S$ and $S_{\mathrm{p}}$ when plotted against valence of cations of $\mathrm{CaCl}_{2}$ and $\mathrm{Na}_{2} \mathrm{SiO}_{3}$. In order to validate the findings of the study, data available in the literature (refer to Table 7) correspond to various other chemical additives, which consist of either monovalent or divalent or trivalent cations, were collected and presented in the form of Fig. 6. It can be observed from Fig. 6 that, in general, both percentage reductions of $S$ and $S_{\mathrm{p}}$ vary linearly with increase in valence such that higher degree of reduction was exhibited by higher valence cations and vice versa. However, it can be noted from the trends depicted in the figure that the percentage reduction range is marginal for $S$, while it is drastic in case of $S_{\mathrm{p}}$ with an increase in valence.
Results reveal that valence has phenomenal influence in reducing $S_{\mathrm{p}}$ than $S$ of a soil. As depicted in the Fig. 6, the scatter in the results of $S_{\mathrm{p}}$ exhibited by monovalent cations is appreciably higher than trivalent cations. The order of efficiency of valence in its increasing form is found to be monovalent to divalent to trivalent. The maximum and minimum percentages reduction of both $S$ and $S_{\mathrm{p}}$ observed from the graphs are listed in Table 8 . The range can be bracketed between 84-40\% and 78-42\%, corresponding to $S$ and $S_{\mathrm{p}}$, respectively.

\section{Influence of Mean Particle Diameter of Additive on Swelling Characteristics}

The physical characteristics such as grain size, shape and particle size distribution of various additives are usually quite distinct, and they show significant change in the behavior of expansive soils. The chemical reactions include pozzolanic reactions, cation exchange capacity, carbonation 
Table 8 Range of maximum and minimum percentage reduction of $S$ and $S_{\mathrm{p}}$ for different valence of cations

\begin{tabular}{lll}
\hline Valence & \multicolumn{2}{l}{ Swelling characteristic (minimum-maximum) } \\
\cline { 2 - 3 } & $S(\%)$ & $S_{\mathrm{p}}(\%)$ \\
\hline Monovalent & $42-68$ & $42-80$ \\
Divalent & $58-82$ & $60-82$ \\
Trivalent & $67-84$ & $75-78$ \\
\hline
\end{tabular}

and cementation, and microfiller effects, which dominantly influence the efficacy of the stabilization process, largely controlled by particles composition of an additive(s) [6265]. Stalin [66] reported that presence of coarser fraction of an additive and its size considerably affects the swelling behavior of an expansive soil. Further, the size of particles has direct bearing on the formation of the number of bonds between clay and additive and water absorption properties $[29,67]$. However, no effort was devoted to investigate the influence of gradational characteristics of additives on the swelling behavior of expansive soils.

With this in view, efforts were also made in this study to evaluate the influence of mean particle diameter, $d_{50}$, of additives on the swelling behavior of expansive soils. Figure 7 depicts the relationship of $d_{50}$ when plotted against $S$ and $S_{\mathrm{p}}$. In order to generalize this relationship, data collected from the literature corresponding to a variety of additives (refer to Table 7) were also superimposed on the plot. It can be noted that the minimum value of $d_{50}$ was obtained for lime, while the maximum value of $d_{50}$ was found for stone dust or quarry dust additives. As depicted in the figure, it can be observed that $d_{50}$ varies linearly with $S$ and $S_{\mathrm{p}}$ such that decrease in the mean particle diameter decreases the percentage reduction of $S$ and $S_{\mathrm{p}}$. As such, trends display similar influence of $d_{50}$ on both $S$ and $S_{\mathrm{p}}$. It can also be noticed from the figures that the smaller is the mean particle diameter of an additive, greater is the percentage reduction of $S$ and $S_{\mathrm{p}}$ and hence, its effectiveness on a soil. Results reveal that up to $100 \%$ reduction in $S$ and $S_{\mathrm{p}}$ can be achieved when employed additives comprising mean particle diameter of lesser than $0.01 \mathrm{~mm}$. As such, results show marginal scatter in the data, although the entire data are fitting well within the $90 \%$ prediction band. This may be attributed to (a) difference in degree of swell potential (viz., low, medium, high, or extremely high) exhibited by a soil mass, (b) distinction in the methodology that can be employed to determine $S$ and $S_{\mathrm{p}}$, (c) type of clay mineral and its percentage content in a given soil mass, etc.

As such, the results suggest that the better correlation between $d_{50}$ and swelling characteristics can be developed when adopted system based on the swell potential like low, medium, high, very high, etc., of soils. Thus, results demonstrate that the mean particle diameter of additive has a definite influence on swelling characteristics of expansive soils.

\section{Concluding Remarks}

This paper demonstrates the performance of a variety of additives such as non-cementitious: stone dust, cementitious: lime and fly ash, and chemical additives: $\mathrm{CaCl}_{2}$ and $\mathrm{Na}_{2} \mathrm{SiO}_{3}$, in reducing the swelling behavior of expansive soils. Results highlight that all the additives are effective in reducing swelling characteristics, and each additive showed its distinct response in stabilizing the expansive
Fig. 7 Percentage reduction versus mean particle diameter of additive a swell potential and b swell pressure

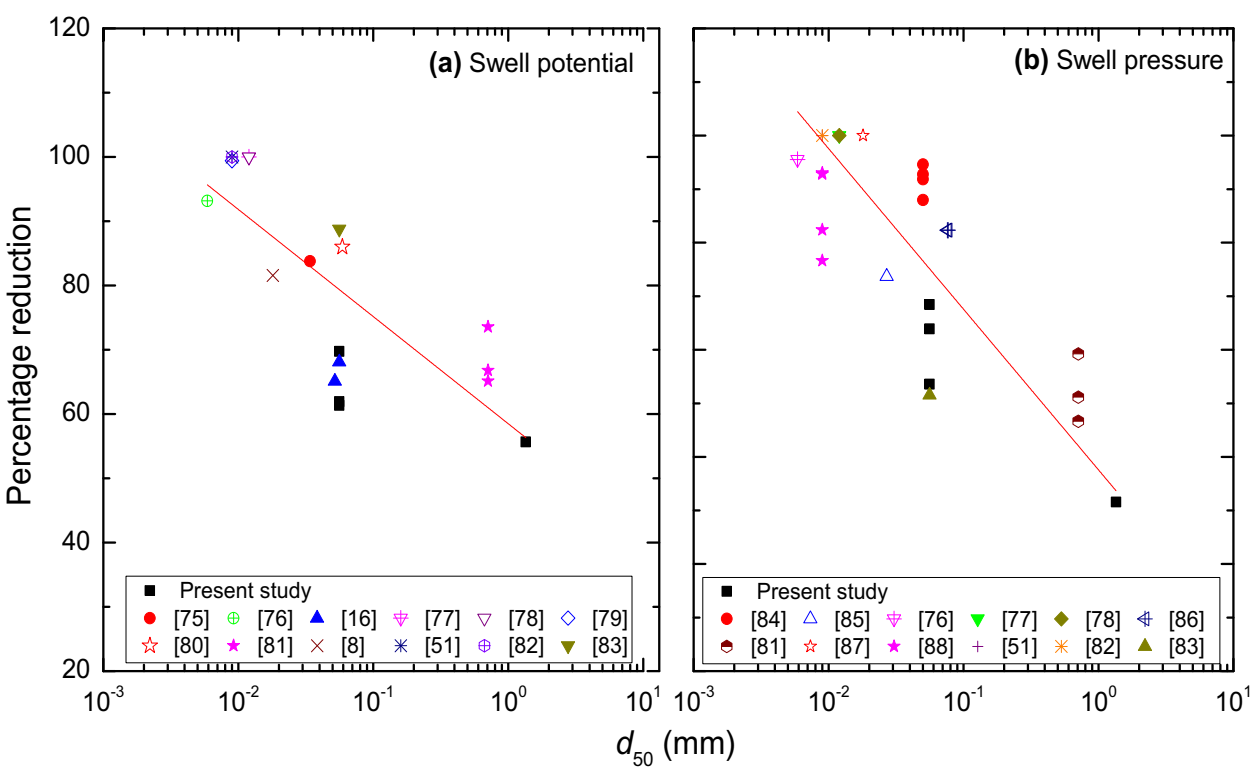


soils. Among the three categories of additives that have been employed for stabilization of three expansive soils, chemical additives exhibit better performance over its counterparts. Efforts were also made in the present study, to investigate the influence of valence of cations and mean particle diameter of additive on swelling characteristics. It has been observed that both valence of cation and the mean particle diameter of additive significantly affect the swelling characteristics. Further, trends clearly show that with increase in valence of cations and decrease in mean particle diameter, both $S$ and $S_{\mathrm{p}}$ decreased to a significant level. As such, results demonstrate that varieties of additives are effective in stabilization of expansive soils, but the selection of a particular additive type seems to be prudent if set on the basis of the prevailing site conditions.

Acknowledgments The authors gratefully acknowledge thanks to Council of Scientific and Industrial Research (CSIR), Government of India, for providing financial support to carry out this work.

\section{References}

1. Chen FH (1988) Foundation on expansive soil: developments in geotechnical engineering, vol 54. Elsevier Publishing Co, Amsterdam

2. Pedarla A, Chittoori B, Puppala AJ (2011) Influence of mineralogy and plasticity index on stabilisation effectiveness of expansive clays. J Transp Res Board 2212:91-99

3. Cokca E (2001) Use of class C fly ashes for the stabilisation of an expansive soil. J Geotech Geoenviron Eng 127:568-573

4. Al-Rawas AA, Taha R, Nelson JD, Beit Al-Shab T, Al-siyabi H (2002) A comparative evaluation of various additives used in the stabilisation of expansive soil. Geotech Test J ASTM 25(2):199-209

5. Phanikumar BR, Sharma RS (2004) Effect of fly ash on engineering properties of expansive soil. J Geotech Geoenviron Eng 130(7):764-767

6. Punthutaecha K, Puppala AJ, Vanapalli SK, Inyang H (2006) Volume change behaviors of expansive soils stabilized with recycled ashes and fibers. J Mater Civ Eng 18(2):295-306

7. Lamara M, Gueddouda MK, Benabed B (2006) Physical and chemical stabilisation of expansive soil. Revue Francaise De Geotechnique 115:25-35

8. Cokca E, Yazic EV, Ozaydi EV (2009) Stabilisation of expansive clays using granulasted blast furnace slag (GBFS) and GBFScement. Geotech Geol Eng 27:489-499

9. Srinivas M, Raju GVRP (2010) Effect of strong chemicals on the swell properties of an expansive clay. In: Proceedings of IGC2010: GEOtrendz, IIT Bombay, pp 613-616. 16-18 Dec

10. Gueddouda MK, Goual I, Lamara M, Smaida A, Mekarta B (2011) Chemical stabilisation of expansive clays from Algeria. Glob J Res Eng 11(5):1-8

11. Jones CJFP, Lamont-Black J, Hall JA (2012) Stabilisation of a railway embankment using electrokinetic geosynthesis. Eng Geol Spec Publ 26:125-139

12. Thompson MR (1969) Engineering properties of lime-soil mixture. J Mater ASTM 4(4):968-969

13. Armani A, Munfakh GA (1972) Lime stabilisation of organic soils. Highway Research Record No. 381, Washington, D.C., pp $37-45$
14. Rogers CD, Glendinning S (2000) Lime requirement for stabilisation. Transportation Research Record No. 1721, National Research Council, Washington D.C., pp 9-18

15. Qubain BS, Seksinsky EJ, Li J (2000) Incorporation subgrade lime stabilisation pavement design. Transportation Record No. 1721, Transportation Research Board, National Research Council Washington, D.C., pp 3-8

16. Cetiner SI (2004) Stabilisation of expansive soil by cayirhan fly ash and desulphogysum. Masters Thesis, The Graduate School of Natural and Applied Sciences, The Middle East Technical University

17. Desai ID, Oza BN (1977) Influence of anhydrous calcium chloride on the shear strength of expansive soil. In: 1st national symposium on expansive soils. HBTI-Kanpur, pp 4.1-4.5

18. Frydman S, Ravina I, Ehrenreich T (1977) Stabilisation of heavy clay with potassium chloride. Geotech Eng 8(2):95-108

19. Yousry M, Mowafy M (1985) Treatment of expansive soil: a laboratory study. Transportation Research Record No. 1032, pp 34-39

20. Rao SM, Rao KS (1994) Ground heave from caustic soda solution spillage: a case study. Soils Found 34(2):13-18

21. Raju GVRP (2001) Evaluation of flexible pavement performance with reinforced and chemical stabilization of expansive soil sub grades. Ph.D. Thesis, Kakitiya University, Warangal

22. Katz LE, Rauch AF, Liljestrand HM, Harmon JS, Shaw KS, Albers H (2001) Mechanisms of soil stabilisation with liquid ionic stabilisation. Transportation Research Record (TRB), Paper No. 01-3228 1757, pp 50-57

23. Mitchell JK, Radd L (1973) Control of volume changes in expansive earth materials. Workshop, on expansive clays and shales in highway design and construction. FHWA, Washington DC, pp 200-217

24. Chandrasekhar BP, Raju GVRP, Murty VR, Krishna HP (1999) Relative performance of lime and calcium chloride on properties of expansive soil for pavement subgrades, In: Proceedings of IGC-99, Calcutta, pp 279-282

25. Petry TM, Armstrong JC (1989) Stabilisation of expansive clay soil. Transp. Res. Rec-1219, Transportation Research Board, Washington D.C., pp 103-112

26. Bell FG (1993) Engineering treatment of soils. E \& FN Spon Publishers, London

27. Sivapullaiah PV, Sridharan A, Raju K (1994) Role of electrolytes on the shear strenght of clayey soil. IGC 1994: developments in geotechnical engineering. Warangal 1:199-202

28. Rao A, Sridevi G (2011) Utilization of industrial wastes in pavements laid over expansive clay subgrades. In: Han J, Alzamora DE (eds) Geo-frontiers 2011: advances in geotechnical engineering, GSP 211, Dallas, pp 4418-4427. 13-16 Mar

29. Gromko GJ (1974) Review of expansive soils. J Geotech Eng Div ASCE 100(GT6):667-687

30. Nelson JD, Miller JD (1997) Expansive soils: problems and practice in foundation and pavement engineering. Wiley, New York 288p

31. Bhuvaneshwari S, Robinson RG, Gandhi SR (2005) Stabilisation of expansive soil using fly ash. Fly Ash Utilisation Programme, TIFAC-DST, New Delhi, VIII, pp 5.1-5.10

32. Ardani A (1992) Expansive soil treatment methods in Colorado. Final Report No.: CDOT-DTD-R-92-2, Denver

33. Johnson LD, Pengelly AD (1993) Chemical and lime stabilization of expansive clay. In: 3rd international conference on case histories in geotechnical engineering, St. Louis, June 1-4, Paper No. 7.10, pp 973-976

34. Peethamparan S, Olek J (2008) Study of the effectiveness of cement kiln dusts in stabilizing Na-montmorillonite clays. J Mater Civ Eng 20(2):137-146 
35. Amadi AA, Eberemu AO, Momoh OH (2013) Use of coir fiber reinforcement technique to improve strength of cement kiln dust treated black cotton soil subgrade. Geosynthetics. Long Beach, pp 223-229. 1-4, April

36. ASTM D 854-14 (2010) Standard test methods for specific gravity of soil solids by water pycnometer. Annual Book of ASTM Standard, ASTM International, vol 04-08, West Conshohocken

37. ASTM D 422-63 (2007) Standard test method for particle-size analysis of soils. Annual Book of ASTM Standard, ASTM International, vol 04-08, West Conshohocken

38. ASTM D 4318-10 (2010) Standard test methods for liquid limit, plastic limit and plasticity index of soils. Annual Book of ASTM Standards, ASTM International, West Conshohocken

39. ASTM D 2487-11 (2011) Standard practice for classification of soils for engineering purposes (unified soil classification system) Annual Book of ASTM Standard, ASTM International, vol 04-08, West Conshohocken

40. ASTM D 698-07 (2007) Standard test methods for laboratory compaction characteristic of soil using standard effort. Annual Book of ASTM standards, ASTM International. West Conshohocken

41. Thakur VKS, Singh DN (2005) Rapid determination of swelling pressure of clay minerals. J Test Eval 33(4):7

42. Snethen DR (1980) Characterization of expansive soils using soils suction data. In: 4th international conference on expansive soils, Denver, pp 54-75

43. Dakshanamurthy V, Ramana V (1973) A simple method of identifying an expansive soil. Soils Found 13(1):97-104

44. Sowers GB, Sowers GF (1970) Introductory soil mechanics and foundation. McMillan Press, New York

45. Grabowska-Olszewska B (1998) Geologia stosowana-właściwości gruntów nienasyconych. Wydawnictwo Naukowe PWN, Warsaw (In Polish)

46. Choi HJ (2005) Soil stabilisation using optimum quantity of calcium chloride with class $\mathrm{F}$ fly ash. Masters Thesis, Texas A\&M University

47. Moayedi H, Huat BBK, Kazemian S, Daneshmand S (2012) Stabilisation of organic soil using sodium silicate system grout. Int J Phys Sci 7(9):1395-1402

48. Fang HY (1991) Foundation engineering handbook, 2nd edn. Springer Science \& Business Media, New York

49. Wang L (2002) Cementitious stabilisation of soil in the presences of sulfate. Ph.D Thesis, Louisiana State University

50. Djedid A, Mamoune SMA, Ikhlef SO, Hadef S (2005) Stabilization des sols gonflants par la chaux et le ciment-Application à la bentonite de Maghnia. Actes de la 2ième Journée d'Etude sur les Sols Gonflants-JESG2, Université Aboubakr Belkaid, Tlemcen (Algérie), 23 Novembre 2005, pp 121-128

51. Siddique A, Hossain MA (2011) Effect of lime stabilisation on engineering properties of an expansive soil for use in road construction. J Soc Transp Traffic Stud 1(4):1-9

52. Barnes AG (1997) Pavement thickness design using reclaimed hydrated Lowa class $\mathrm{C}$ fly as a base material. Masters Thesis, Lowa State University

53. Eze-Uzomaka OJ, Agbo D (2010) Suitability of quarry dust as improvement to cement stabilized-laterite for road bases. EJGE 15(Bundle K):1053-1066

54. Mackiewicz SM, Ferguson EG (2005) Stabilization of soil with self-cementing coal ashes. World of Coal Ash (WOCA), Lexington, Kentucky, pp 1-7. 11-15 April

55. Sivapullaiah PV, Prashanth JP, Sridharan A, Narayana BV (1998) Reactive silica and strength of fly ashes. Geotech Goel Eng $16: 239-250$

56. Makusa GP (2012) Soil stabilization methods and materials in engineering practice. State of the Art Report, Luleå University of Technology, Luleå
57. Murty VR, Praveen GV (2008) Use of chemically stabilized soil as cushion material below light weight structures founded on expansive soils. J Mater Civ Eng 20(5):392-400

58. Tingle JS, Santoni RL (2003) Stabilization of clay soils with nontraditional additives. Transp Res Record J Transp Res Board 1819(1):72-84

59. Terzaghi K, Peck RB, Mesri G (1996) Soil mechanics in engineering practice, 3rd edn. Wiley, New York

60. Tingle JS, Newman JK, Larson SL, Weiss CA, Rushing JF (2007) Stabilization mechanisms of non-traditional stabilizers. Transp Res Record J Transp Res Board 1989(1):59-67

61. Mitchell JK, Soga K (2004) Fundamentals of soil behavior, 3rd edn. Wiley, New York 577p

62. Chapman HD (1965) In: Black CA et al (eds) Cation exchange capacity in methods of soil analysis. American Society of Soil Agronomy, Madison, pp 891-901

63. Katti DR, Shanmugasundaram V (2001) Influence of swelling on the microstructure of expansive clays. Can Geotech J 38:175-182

64. Stavridakis E (2005) Presentation and assessment of clay influence on engineering parameters of cement treated clayey mixtures. EJGE 10(Bundle A)

65. Louafi B, Bahar R (2012) Sand: an additive for stabilization of swelling clay soils. Int J Geosci 3(4):719-725

66. Stalin VK (1995) Factors and mechanisms controlling the index properties and engineering behaviour of soil mixtures. Ph.D. Thesis, IISc Bangalore

67. El-Sohby MA, Rabba EA (1981) Some factors affecting swelling of clayey soils. Geotech Eng J 12:19-39

68. Rao KD, Anusha M, Pranav PRT (2012) Effect of ferric chloride and rice husk ash in stabilization of expansive soil for pavement subgrade. Int J Eng Sci Adv Technol 2(2):146-153

69. Abdullah WS, Al-Abadi AM (2010) Cationic-electrokinetic improvement of an expansive soil. Appl Clay Sci 47(3):343-350

70. Belabbaci Z, Mamoune SMA, Bekkouche A (2013) Laboratory study of the influence of mineral salts on swelling $\left(\mathrm{KCl}, \mathrm{MgCl}_{2}\right)$. Earth Sci Res 2:135-142

71. Radhakrishnan G, Kumar MA, Raju GVRP (2014) Swelling properties of expansive soils treated with chemicals and fly ash. Am J Eng Res 3(4):245-250

72. Heeralal M, Murty VR, Praveen GV, Shankar S (2012) Influence of calcium chloride and sodium silicate on index and engineering properties of bentonite. In: Proceedings of international conference on chemical, environmental science and engineering, Pattaya, pp 52-57. 28-29, July

73. Urena C, Azanon JM, Corpas F, Nieto F, Leon C, Perez L (2013) Magnesium hydroxide, seawater and olive mill wastewater to reduce swelling potential and plasticity of bentonite soil. Constr Build Mater 45:289-297

74. Azam S, Abduljauwad SN, Al-Shayea NA, Al-Amoudi BOS (2000) Effects of calcium sulfate on swelling potential of an expansive clay. Geotech Test J ASTM 23(4):389-403

75. Cai Y, Shi B, Ng CWW, Tang CS (2006) Effect of polypropylene fibre and lime admixture on engineering properties of clayey soil. Eng Geol 87(3-4):230-240

76. Kalkan E (2009) Influence of silica fume on the desiccation cracks on compacted clayey soil. Appl Clay Sci 43:296-302

77. Nalbantoglu Z, Gucbilmez E (2002) Utilization of an industrial waste in calcareous expansive clay stabilisation. Geotech Test $\mathbf{J}$ 25(1):78-84

78. Nalbantoglu Z (2004) Effectiveness of class C fly ash as an expansive soil stabilizer. Constr Build Mater 18:377-381

79. Zhang JR, Cao X (2002) Stabilisation of expansive soil by lime and fly ash. J Wuhan Univ Technol Mater Sci Ed 17(4):73-78

80. Negi C, Yadav RK, Singhai AK (2013) Effect of silica fume on index properties of black cotton soil. Int $\mathrm{J}$ Sci Eng Res 4(8):828-833 
81. ElKholy SM (2008) Improving the characteristics of expansive soil using coarse grained soil. J Eng Comput Sci 1(2):71-81

82. Al-Rawas AA, Hago AW, Hilal AS (2005) Effect of lime and Sarooj (Artificial pozzolan) on the swelling potential of an expansive soil from Oman. Build Environ 40:681-687

83. Phanikumar BR (2009) Effect of lime and fly ash on swell consolidation and shear strength characteristics of expansive clays: a comparative study. Geomech Geoeng 4(2):175-181

84. Attom MF, Al-Sharif MM (1998) Soil stabilisation with burned olive waste. Appl Clay Sci 13(3):219-230
85. Mollamahmutoglu M, Yilmaz Y (2001) Potential use of fly ash and bentonite mixture as liner or cover at waste disposal areas. Environ Geol 40(11/12):1316-1324

86. Sabat AK (2012) Stabilisation of expansive soil using waste ceramic dust. EJGE 17:3915-3926

87. Bose B (2012) Geo-engineering properties of expansive soil stabilisation with fly ash. EJGE 17:1339-1353

88. Kalkan E, Akbulut S (2004) The positive effects of silica fume on the permeability, swelling pressure and compressive strength of natural clay liners. Eng Geol 73:145-156 